\title{
PENGUJIAN BEBERAPA ALTERNATIF TEKNIK PENANAMAN TANAMAN KARET DI LAHAN GAMBUT
}

\author{
Testing of Some Alternative Rubber Planting Techniques in Peatland \\ Jamin SAPUTRA $^{1^{*}}$, Charlos Togi STEVANUS ${ }^{1}$, \\ Risal ARDIKA ${ }^{1}$ dan Thomas WIJAYA ${ }^{2}$ \\ ${ }^{1}$ Balai Penelitian Sembawa, Pusat Penelitian Karet \\ Jalan Palembang - Pangkalan Balai KM 29 Palembang 30001 Sumatera Selatan \\ *Email : jamincomsu@yahoo.com \\ ${ }^{2}$ Pusat Penelitian Karet \\ Jalan Salak Nomor 1 Bogor 16151 Jawa Barat
}

Diterima : 20 Desember 2018 / Disetujui : 27 Desember 2018

\begin{abstract}
The ideal land for growing rubber plantations is increasingly limited hence many farmers and companies are looking for rubber development land in non-traditional areas such as peatlands. Rubber planting in peat areas has limitation factors such as poor nutrient of peat and plants will fall when plants growing up. There was still limited information on the results of research which was related to rubber plants growth on peatlands. Research was conducted to determine growth and how to overcome the constraints of planting rubber on peatlands. This research was carried out on peatlands with a depth of $1.5-2 \mathrm{~m}$ and maturity level of peat is sapric. IRR 118 rubber clone was used in this research. This study was an experimental study, using a randomized block design with four treatments and six replications. The treatments tested are 1) Control (normal way of planting with conventional planting material), 2) Planting inside (planting holes are made deeper hence planting is carried out until the first umbrella and using conventional seeds), 3) Modification of planting material (grafting height of $30 \mathrm{~cm}$ ) and 4) Material modification (grafting height of $50 \mathrm{~cm}$ ). The results showed that growth of IRR 118 rubber clone had good growth so that average rubber girth at the age of five years can reached $45 \mathrm{~cm}$. The treatment effect of planting techniques on growth has not been seen rubber plant with inclined position and fall down at the age 5 years.
\end{abstract}

Keywords: rubber growth, IRR 118 clone, modification of planting material, peatland

\section{Abstrak}

Lahan yang ideal untuk pertumbuhan tanaman karet semakin terbatas sehingga banyak petani dan perusahaan mencari lahan pengembangan karet di daerah non tradisional seperti lahan gambut. Penanaman karet pada areal gambut terdapat hambatan seperti miskinnya hara gambut dan tanaman akan tumbang pada saat tanaman sudah besar. Masih terbatasnya informasi hasil penelitian terkait pertumbuhan tanaman karet di lahan gambut, sehingga penelitian ini dilakukan untuk mengetahui pertumbuhan dan cara mengatasi kendala penanaman karet di lahan gambut. Penelitian ini dilaksanakan di lahan gambut dengan kedalaman 1,5 - $2 \mathrm{~m}$ dan tingkat kematangan gambut sapris. Klon karet yang digunakan adalah IRR 118. Penelitian ini merupakan penelitian eksperimen, menggunakan rancangan acak kelompok dengan empat perlakuan dan enam ulangan. Perlakuan yang diuji adalah 1) Kontrol (cara penanaman biasa dengan bahan tanam konvensional), 2) Penanaman dalam (lubang tanam dibuat lebih dalam sehingga penanaman dilakukan sampai payung pertama dan menggunakan bibit konvensional), 3) Modifikasi bahan tanam (ketinggian okulasi $30 \mathrm{~cm}$ ), dan 4) Modifikasi bahan (ketinggian okulasi $50 \mathrm{~cm}$ ). Hasil penelitian menunjukkan bahwa pertumbuhan tanaman karet klon IRR 118 memiliki pertumbuhan yang baik sehingga pada umur lima tahun rata-rata lilit batangnya telah mencapai $45 \mathrm{~cm}$. Pengaruh perlakuan teknik penanaman terhadap 
pertumbuhan dan tanaman yang miring atau tumbang sampai dengan umur tanaman lima tahun belum terlihat.

Kata kunci: Pertumbuhan tanaman karet, klon IRR 118, modifikasi bahan tanam, gambut

\section{PENDAHULUAN}

Tanaman karet merupakan tanaman yang mempunyai daya adaptasi luas dan dapat tumbuh pada berbagai kondisi tanah dan iklim, namun pertumbuhannya akan lebih optimal jika ditanam pada daerah yang mempunyai kondisi lingkungan yang lebih sesuai Dijkman, 1951 (Rao \& Vijayakumar, 1992; Watson, 1989). Perluasan areal banyak terkendala karena ketersediaan lahan kering sudah mulai sulit dicari sehingga banyak yang mulai mencoba untuk menanam tanaman karet pada lahan-lahan yang marjinal seperti lahan pasang surut dan lahan gambut. Dalam usaha penanaman pada areal gambut terdapat hambatan seperti tanaman akan tumbang pada saat tanaman sudah besar.

Gambut adalah lahan yang tanahnya mengandung bahan organik lebih dari 30\% dan dikategorikan sebagai lahan gambut apabila lahan mempunyai ketebalan gambutnya lebih dari $50 \mathrm{~cm}$. Lahan yang ketebalan gambutnya kurang dari $50 \mathrm{~cm}$ disebut lahan bergambut. Gambut terbentuk dari hasil dekomposisi bahanbahan organik seperti daun, ranting, semak belukar, yang berlangsung dalam kecepatan lambat dan suasana anaerob. Fahmuddin dan Subiksa (2008), melaporkan karakteristik fisik gambut yang penting dalam pemanfaatannya untuk pertanian meliputi kadar air, berat isi (bulk density, $\mathrm{BD}$ ), daya menahan beban (bearing capacity), penurunan permukaan (subsidance), dan mengering tidak balik (irriversible drying). Kadar air tanah gambut berkisar antara $100-1.300 \%$ dari berat keringnya (Mutalib et al., 1991). Kadar air yang tinggi menyebabkan BD menjadi rendah, gambut menjadi lembek dan daya menahan bebannya rendah (Widjaja-Adhi, 1997). BD tanah gambut lapisan atas bervariasi antara 0,1 sampai $0,2 \mathrm{~g} / \mathrm{cm}^{3}$ tergantung pada tingkat dekomposisinya. Gambut fibrik yang umumnya berada di lapisan bawah memiliki BD lebih rendah dari $0,1 \mathrm{~g} / \mathrm{cm}^{3}$, tapi gambut pantai dan gambut di jalur aliran sungai bisa memiliki $\mathrm{BD}>0,2$ $\mathrm{g} / \mathrm{cm}^{3}$, karena adanya pengaruh tanah mineral (Tie \& Lim, 1991). Volume gambut akan menyusut bila lahan gambut didrainase, sehingga terjadi penurunan permukaan tanah (subsidance). Selain karena penyusutan volume, subsidance juga terjadi karena adanya proses dekomposisi dan erosi. Sifat fisik tanah gambut lainnya adalah sifat mengering tidak balik. Gambut yang telah mengering, dengan kadar air $<100 \%$ (berdasarkan berat), tidak bisa menyerap air lagi kalau dibasahi. Gambut yang mengering ini sifatnya sama dengan kayu kering yang mudah hanyut dibawa aliran air dan mudah terbakar dalam keadaan kering(Widjaja-Adhi, 1988).

Berdasarkan tingkat kesuburannya, gambut di Indonesia tergolong ke dalam gambut oligotropik (miskin) sampai mesotropik (sedang) dan hanya sedikit yang tergolong ke dalam golongan eutropik (subur). Berdasarkan kematangannya, gambut dibedakan menjadi 3, yaitu fibrik (apabila bahan vegetatif aslinya masih dapat dikenali atau baru sedikit mengalami dekomposisi), hemik (apabila tingkat dekomposisinya sedang), dan saprik (apabila tingkat dekomposisinya telah lanjut). Tanah gambut memiliki $\mathrm{pH}$ rendah, kapasitas tukar kation (KTK) tinggi, kejenuhan basa rendah, kandungan $\mathrm{K}, \mathrm{Ca}, \mathrm{Mg}$, P serta unsur mikro (Cu, Zn, Mn, dan B) rendah (Fahmuddin \& Subiksa, 2008).

Lahan gambut Indonesia masih sangat luas dan potensial sebagai lahan pengembangan lahan perkebunan. Balai Besar Penelitian dan Pengembangan Sumberdaya Lahan Pertanian (2011) mengeluarkan peta sebaran dan luas lahan gambut Indonesia. Berdasarkan hasil perhitungan secara spasial dari pembaharuan peta gambut menggunakan data hasil-hasil penelitian terbaru, maka luas total lahan gambut di 3 pulau utama yaitu Sumatera, Kalimantan dan Papua adalah 14.905.574 Ha. Sedangkan luas lahan gambut dangkal $(<100 \mathrm{~cm})$ adalah 5.241.348 Ha. Lahan gambut terluas 
terdapat di pulau Sumatera, yaitu 6.436.649 $\mathrm{Ha}$ dengan luasan berimbang antara kedalaman dangkal (50-100 cm) sampai sangat dalam $(>300 \mathrm{~cm})$. Sebaran lahan gambut terluas di Sumatera terdapat di Provinsi Riau, kemudian Sumatera Selatan dan Jambi. Sedangkan provinsi lainnya < $262.000 \mathrm{Ha}$.

Sampai saat ini belum ada perkebunan karet dalam skala luas yang ditanam pada lahan gambut. Secara sporadis lahan gambut ditanami karet oleh masyarakat dan informasi lengkap tentang kinerja tanaman karet pada lahan gambut belum tersedia. Beberapa pustaka menyatakan bahwa kedalaman gambut $>50$ $\mathrm{cm}$ merupakan faktor pembatas berat. Watson (1989) dan Yew (1991), menyatakan bahwa lahan gambut merupakan kendala berat baik dilihat dari kemampuannya menopang batang dan juga dalam hal mensuplai hara bagi tanaman karet.

Yoon dan Leong (1985) melaporkan hasil penelitian di tanah mineral bahwa bibit tanaman karet dua payung apabila ditanam sampai payung pertama, maka pada saat tanaman sudah berumur 9 tahun diamati ternyata batang atas yang tertanam tidak mengeluarkan akar dan sebaliknya yang mengeluarkan akar itu hanya pada batang bawah yang ditanam lebih dalam dengan menggunakan teknik okulasi 30 dan $45 \mathrm{~cm}$ di atas permukaan tanah sehingga bisa dilakukan penanaman yang lebih dalam. Hal ini merupakan salah satu cara yang dapat diterapkan untuk mengatasi terjadinya subsidance sehingga diharapkan cengkraman tanaman masih mampu untuk menahan tanaman tetap tidak miring atau tumbang.

Melihat cukup besarnya potensi lahan gambut dangkal dan belum tersedianya informasi yang cukup banyak tentang perkebunan karet pada lahan gambut sehingga dianggap penting melakukan penelitian yang bertujuan untuk mengetahui pertumbuhan dan cara mengatasi kendala penanaman tanaman karet pada lahan gambut.

\section{BAHAN DAN METODE}

\section{Kondisi Umum Lokasi Penelitian}

Penelitian dilakukan di lahan milik petani di Desa Sungai Rengit, Kecamatan Talang Kelapa, Kabupaten Banyuasin, Provinsi Sumatera Selatan. Lahan gambut pada lokasi penelitian termasuk pada lahan gambut dangkal dengan ketebalan gambut $1,5 \mathrm{~m}$ dan tingkat kematangan gambut saprik. Hasil analisis sifat fisik gambut menunjukkan bahwa bobot isi sebesar 0,53 $\mathrm{g} / \mathrm{cm}^{3}$. Tingginya bobot isi gambut pada lokasi penelitian dibandingkan bobot isi gambut pada umumnya dikarenakan tingkat kematangannya termasuk dalam kategori saprik. Selain itu menurut Tie dan Lim (1991) gambut di jalur aliran sungai bisa memiliki bobot isi $>0,2 \mathrm{~g} / \mathrm{cm}^{3}$, karena adanya pengaruh tanah mineral. Hasil analisis sifat kimia gambut disajikan pada Tabel 1. Berdasarkan kriteria hara tanah untuk tanaman karet (Adiwiganda et al.,

Tabel 1. Hasil analisis sifat kimia gambut di lokasi penelitian

Table 1. Results of analysis of the chemical properties of peat at the study site

\begin{tabular}{ccc}
\hline $\begin{array}{c}\text { Parameter } \\
\text { Parameter }\end{array}$ & $\begin{array}{c}\text { Lahan penelitian } \\
\text { Research site }\end{array}$ & $\begin{array}{c}\text { Kriteria* } \\
\text { Criteria }\end{array}$ \\
\hline $\mathrm{pH} \mathrm{H} \mathrm{H}_{2} \mathrm{O}$ & 4,17 & Sangat Masam \\
$\mathrm{C}-$ Srganik $\%)$ & 13,74 & Tinggi \\
$\mathrm{N}(\%)$ & 0,64 & Sangat Rendah \\
$\mathrm{P}_{2} \mathrm{O}_{5}(\mathrm{ppm})$ & 1,28 & Sangat Rendah \\
$\mathrm{K}(\mathrm{me} / 100 \mathrm{gr})$ & 0,018 & Rendah \\
$\mathrm{Ca}(\mathrm{me} / 100 \mathrm{gr})$ & 0,35 & Sedang \\
$\mathrm{Mg}(\mathrm{me} / 100 \mathrm{gr})$ & 0,706 & Sangat Tinggi \\
$\mathrm{KTK}(\mathrm{me} / 100 \mathrm{gr})$ & 87,69 & .
\end{tabular}

* Berdasarkan klasifikasi hara tanah untuk tanaman karet (Adiwiganda et al., 1994)

* Based on soil nutrient classification for rubber plant 
1994), lokasi penelitian memiliki kandungan hara $(\mathrm{N}, \mathrm{P}, \mathrm{K}, \mathrm{Ca}, \mathrm{Mg})$ yang rendah sampai tinggi, namun belum terlihat gejala kekurangan hara. Hal ini menunjukkan bahwa pemupukan perlu dilakukan sebagai sumber hara bagi tanaman, terutama unsur hara $\mathrm{P}, \mathrm{K}$ dan $\mathrm{Mg}$. Gambut memiliki nilai $\mathrm{pH}$ yang sangat masam $(4,17)$, C-Organik dan KTK yang sangat tinggi.

\section{Metode Penelitian}

Penelitian dimulai pada tahun 20132018 dan penanaman dilakukan pada bulan Oktober 2013. Penelitian ini menggunakan bibit konvensional (bibit polibeg dua payung) dan bibit yang dimodifikasi dengan cara okulasi $30 \mathrm{~cm}$ dan $50 \mathrm{~cm}$ di atas permukaan tanah. Klon karet yang digunakan adalah klon IRR 118, penggunaan klon ini dikarenakan bentuk tajuk tanaman seperti cemara (Lasminingsih, 2013), sehingga mengurangi berat tajuk dan diharapkan mengurangi tanaman miring atau tumbang.

Penelitian ini merupakan penelitian eksperimen, menggunakan rancangan acak kelompok (Completely Randomized Design) dengan empat perlakuan dan empat ulangan. Perlakuan yang diuji adalah sebagai berikut :

1) Kontrol

Cara penanaman biasa dengan bahan tanam konvensional.

2) Penanaman Dalam

Lubang tanam dibuat lebih dalam (60 $\mathrm{cm})$ sehingga penanaman lebih dalam sampai payung pertama dan menggunakan bibit konvensional dua payung.

3) Modifikasi Bahan Tanam 1

Bahan tanam menggunakan bahan tanam dengan ketinggian okulasi $30 \mathrm{~cm}$ dari permukaan tanah dan dilakukan penanaman dalam $(60 \mathrm{~cm})$

4) Modifikasi Bahan Tanam 2

Bahan tanam menggunakan bahan tanam dengan ketinggian okulasi $50 \mathrm{~cm}$ dari permukaan tanah dan dilakukan penanaman lebih dalam $(80 \mathrm{~cm})$

Pengendalian gulma dilakukan sebanyak empat kali setahun dan dosis pemupukan menggunakan dosis umum ( Wijaya \& Hidayati, 2012). Pemupukan dilakukan sebanyak empat kali dalam setahun. Penelitian menggunakan jarak tanam anjuran yakni $6 \times 3 \mathrm{~m}$. Setiap plot perlakuan menggunakan 49 tanaman. Pengamatan dilakukan pada 25 tanaman di bagian dalam dari plot penelitian. Adapun parameter pengamatan yang dilakukan, antara lain :

1) Lilit batang tanaman

Lilit batang diukur pada ketinggian 100 $\mathrm{cm}$ dari pertautan okulasi dan diukur pada saat tanaman berumur satu tahun dan selanjutnya setiap tiga bulan.

2) Kedalaman muka air gambut

Kedalaman muka air gambut diukur dengan cara mengukur kedalaman air di dalam pipa paralon yang telah dipasang. Pengukuran dilakukan bersamaan dengan pengukuran lilit batang.

3) Penurunan gambut

Penurunan gambut diukur dengan cara mengukur tinggi paralon dari permukaan gambut. Pipa paralon dipasang pada lahan penelitian yang dinding paralonnya telah dilubangi sehingga air bisa masuk ke dalam paralon. Pengukuran dilakukan bersamaan dengan pengukuran lilit batang.

Data lilit batang dianalisis statistik untuk mengetahui pengaruh perlakuan terhadap pertumbuhan tanaman karet di lahan gambut. Analisis statistik yang digunakan adalah analisis sidik ragam dengan uji lanjut Duncan. Analisis statistik data pertumbuhan menggunakan program SPSS versi 16.

\section{HASIL DAN PEMBAHASAN}

\section{Tinggi Muka Air dan Penurunan Gambut}

Pengukuran muka air gambut dan penurunan gambut dilakukan bersamaan dengan pengukuran pertumbuhan tanaman. Pada lokasi penelitian terdapat saluran drainase yang baik sehingga muka air gambut tetap terjaga dan tidak pernah terjadi genangan. Fluktuasi muka air gambut (Gambar 1) sangat dipengaruhi oleh kondisi curah hujan pada saat pengamatan. Data sampai 60 bulan setelah tanam (BST), pada bulan April 2015 (18 BST) merupakan ketinggian muka air gambut tertinggi $(27 \mathrm{~cm}$ dari permukaan gambut) akibat musim hujan (Gambar 2). Sementara itu, Oktober 2015 (24 BST) merupakan musim kemarau yang panjang sehingga muka air gambut > 


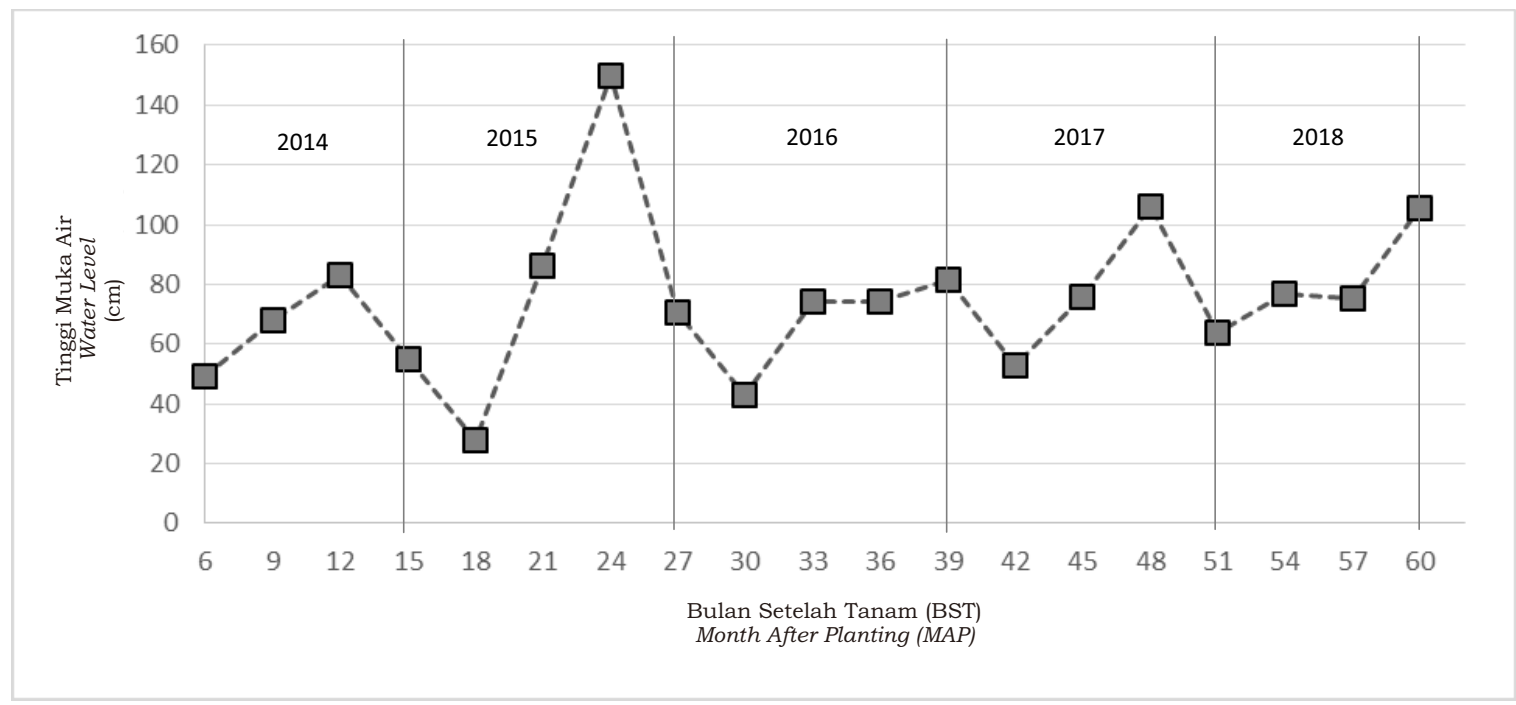

Gambar 1. Fluktuasi tinggi muka air Figure 1. Water level fluctuations

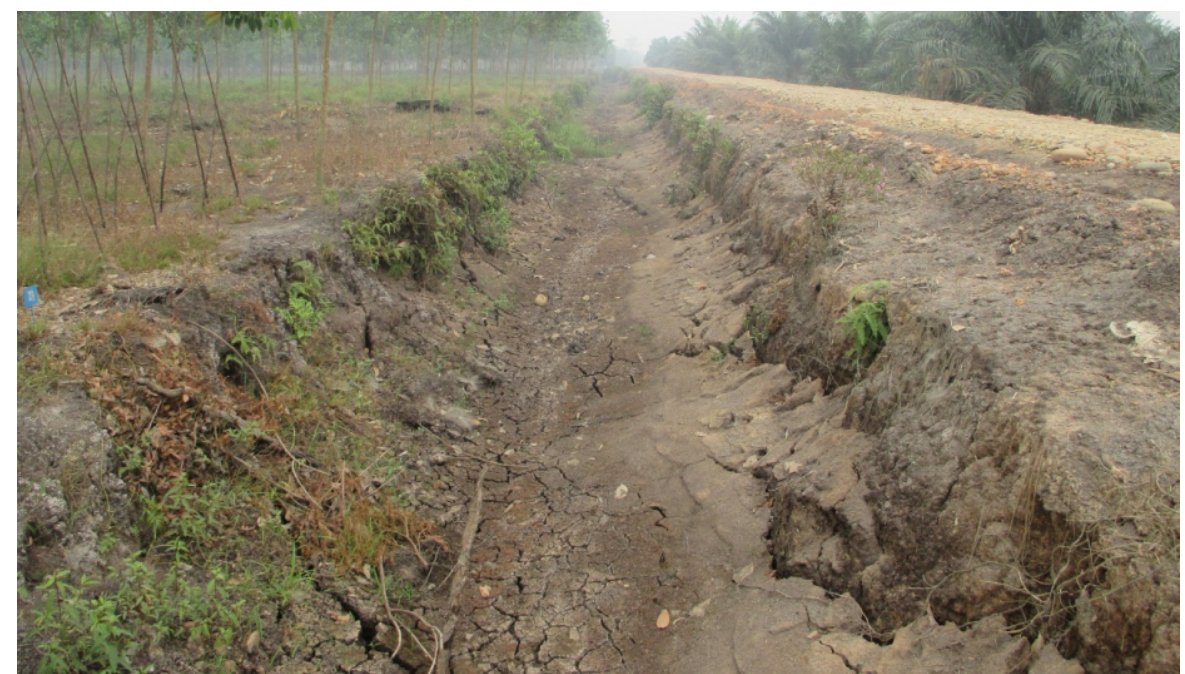

Gambar 2. Kondisi saluran drainase Oktober 2015

Figure 2. Condition of the drainage channel in October 2015

$150 \mathrm{~cm}$ dan saluran drainase juga kering (Gambar 3). Musim kemarau tahun 2015 tidak berdampak terhadap penurunan pertumbuhan tanaman. Hal ini terlihat pertambahan lilit batang pada tahun 2015 masih mencapai $\pm 11 \mathrm{~cm}$ (Tabel 2).

Hasil destruktif pengamatan akar satu pohon dari setiap perlakuan menunjukkan bahwa kedalaman akar tanaman rata-rata $70 \mathrm{~cm}$, hal ini menunjukkan bahwa perakaran tanaman karet tidak terendam dan berkembang dengan baik sehingga tidak mengganggu pertumbuhannya (Gambar 4).
Menurut Setiawan dan Andoko (2005) akar tanaman karet terdapat akar tungang dan kedalaman akar tunggal mencapai 1-2 m, namun untuk tanaman karet asal bahan tanam stum mata tidur kurang dari satu meter karena pada saat stum mata tidur akar tunggangnya dipotong. Sihotang (1994) menyebutkan bahwa apabila drainase di lahan gambut dapat dijaga sampai permukaan air tanah minimal $1,5 \mathrm{~m}$, tanaman karet masih dapat tumbuh dengan baik pada tanah gambut dengan ketebalan gambut hingga $2 \mathrm{~m}$. 

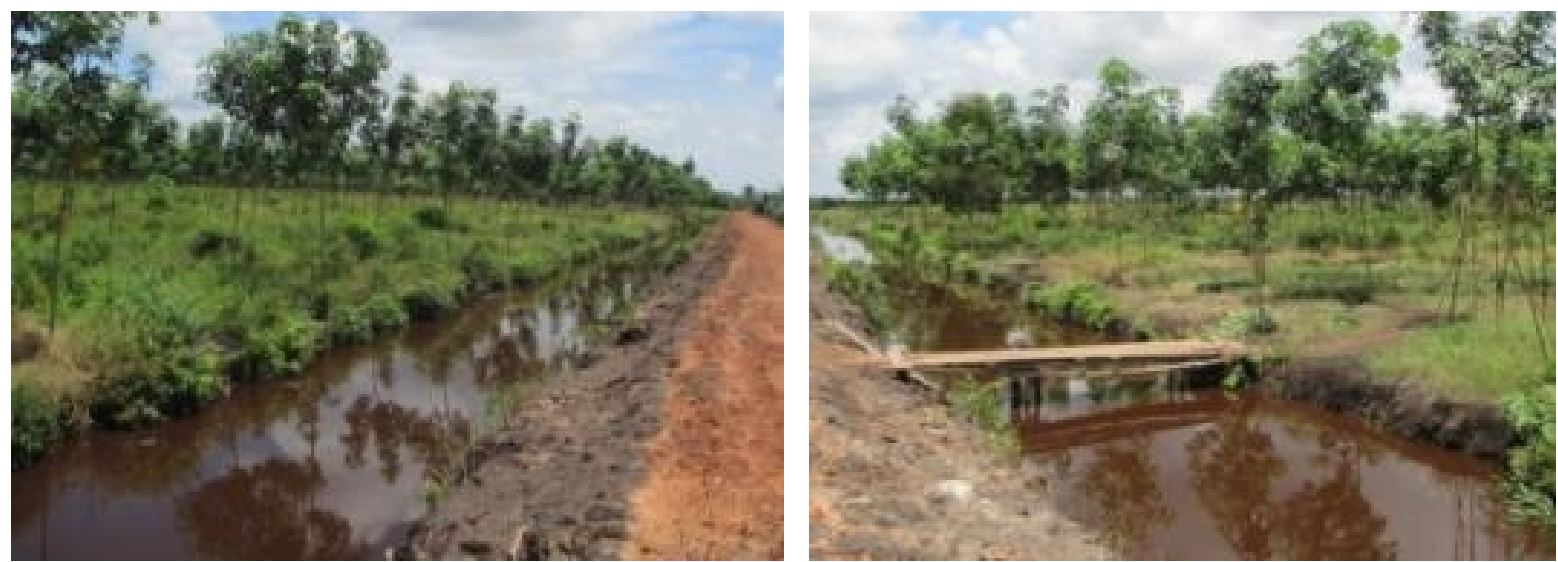

Gambar 3. Muka air gambut pada musim hujan

Figure 3. Peat water faces during the rainy season

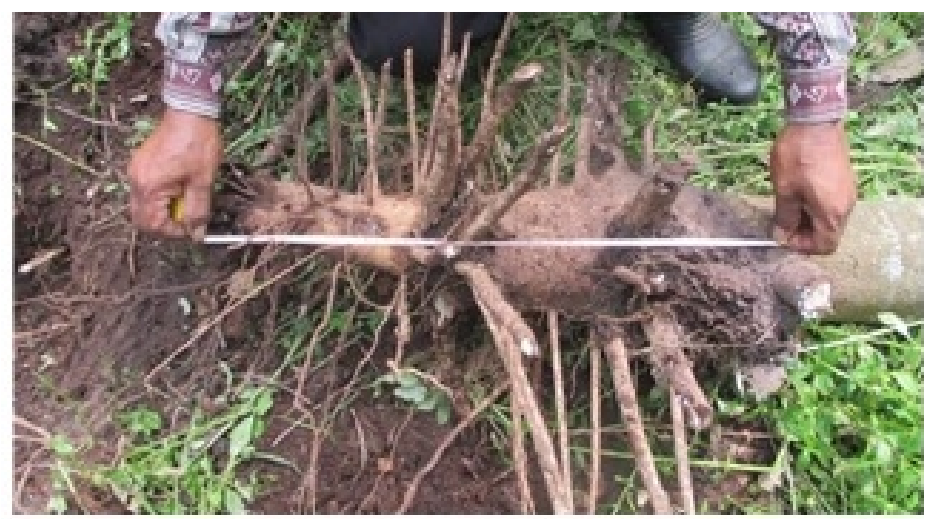

Gambar 4. Akar tanaman karet di lahan gambut Figure 4. Roots of rubber plants on peatlands

Penurunan gambut sampai dengan umur tanaman 18 BST (April 2015) cukup besar yakni $20 \mathrm{~cm}$. Dari grafik penurunan gambut (Gambar 5), terlihat bahwa pada awal penanaman terjadi penurunan yang cukup tinggi dan setelah tanaman berumur 24 BST penurunan gambut menurun. Sepanjang tahun 2017 (36-48 BST), penurunan gambut hanya bertambah 1,38 $\mathrm{cm}$. Pembuatan saluran drainase pada lahan gambut berpotensi meningkatkan oksigen sekitar 1,4-1,9 lebih tinggi dibandingkan pada saat keadaan tergenang/anaerob (Silins \& Rothwell, 1999). Kondisi tersebut mengubah kondisi mikroba anaerob (seperti bakteri, fungi, dan jamur) menjadi mikroba aerob. Menurut Landry dan Rochefort (2012) bahwa dekomposisi bahan organik dalam keadaan aerob dapat menjadi 50 kali lebih cepat dibandingkan keadaan anaerob. Hal ini yang dapat menyebabkan penurunan gambut yang cukup tinggi hingga tanaman karet berumur 12 BST. Selain itu, drainase juga dapat menyebabkan perubahan struktur gambut menjadi hidrofobik (Holden et al., 2006), sehingga dapat menyebabkan penyusutan volume gambut sehingga permukaaannya menjadi turun. Berdasarkan data pertumbuhan Tabel 2, penurunan gambut (Gambar 5) tidak mempengaruhi pertumbuhan tanaman. 


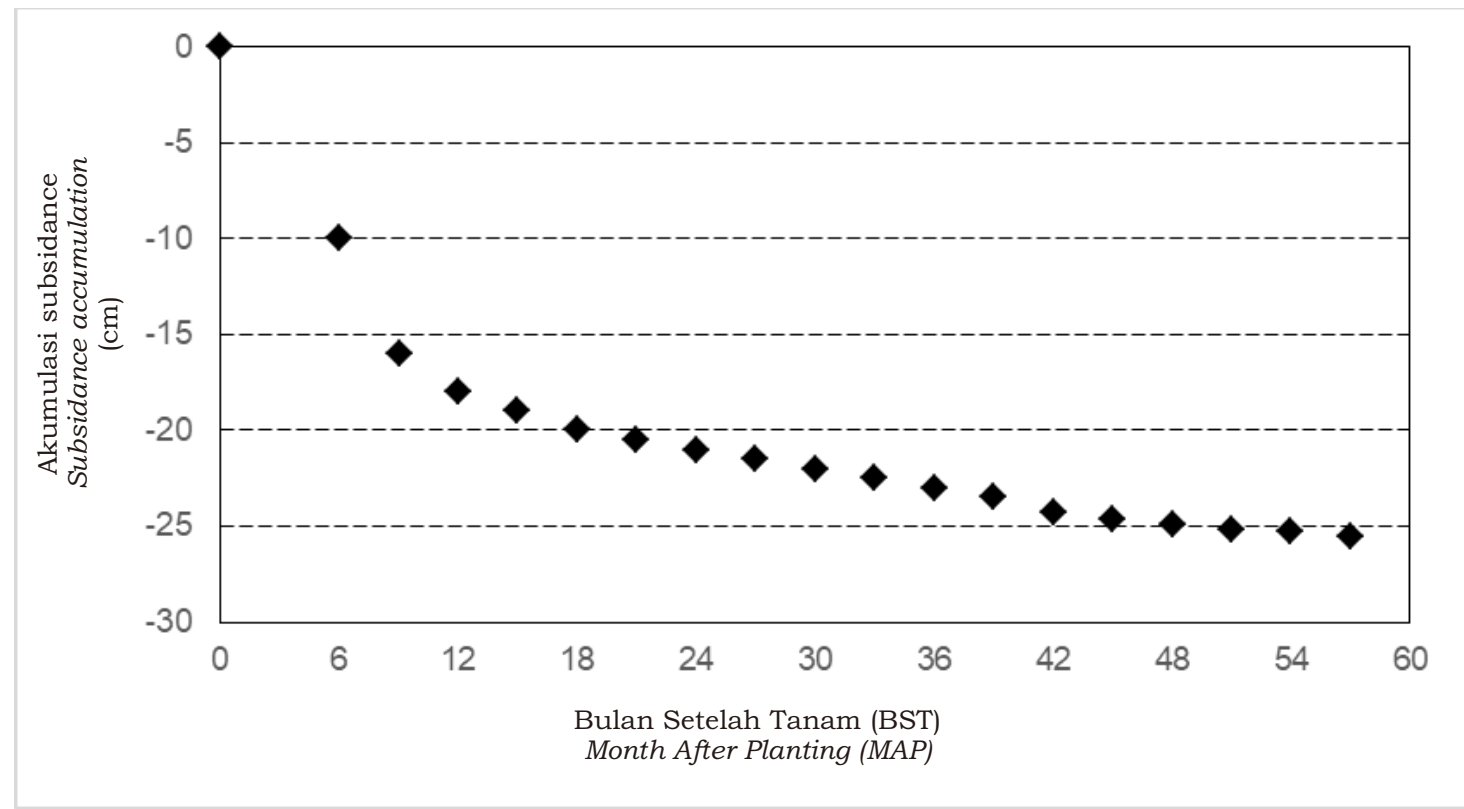

Gambar 5. Penurunan gambut pada lokasi penelitian

Figure 5. Peat subsidance in the study location

Tabel 2. Pertumbuhan tanaman karet klon IRR 118 di lahan gambut Table 2. Growth of IRR 118 rubber clone on peatlands

\begin{tabular}{cccccc}
\hline Perlakuan & 12 BST & 24 BST & 36 BST & 48 BST & 60 BST \\
Treatments & $12 \mathrm{MAP}$ & $12 \mathrm{MAP}$ & $36 \mathrm{MAP}$ & $48 \mathrm{MAP}$ & 60 MAP \\
\hline Kontrol & $9,09 \mathrm{tn}$ & $20,51 \mathrm{tn}$ & $29,35 \mathrm{tn}$ & $37,74 \mathrm{tn}$ & $45,03 \mathrm{tn}$ \\
Penanaman dalam & 8,10 & 19,15 & 29,40 & 37,96 & 45,68 \\
Okulasi $30 \mathrm{~cm}$ & 8,42 & 19,65 & 29,96 & 37,76 & 45,09 \\
Okulasi $50 \mathrm{~cm}$ & 8,32 & 19,97 & 29,03 & 37,13 & 45,20 \\
\hline
\end{tabular}

Keterangan: tn (tidak nyata)

\section{Pertumbuhan Tanaman}

Hasil pengukuran lilit batang disajikan pada Tabel 2. Dari hasil tersebut terlihat bahwa pada umur 60 BST (lima tahun), tanaman karet pada lahan gambut telah matang sadap. Tanaman karet telah matang sadap apabila ukuran lilit batang minimal $45 \mathrm{~cm}$. Pemeliharaan tanaman karet yang tidak standar akan menghambat pertumbuhan, seperti yang dilaporkan Saputra et al (2012) bahwa tanaman karet rakyat pada lahan gambut umur lima tahun yang perawatannya kurang baik lilit batangnya hanya $37,6 \mathrm{~cm}$. Hasil penelitian (Tabel 2), pada umur 12 sampai 36 BST menunjukkan perlakuan kontrol memiliki rata-rata lilit batang paling besar dibandingkan dengan perlakuan lainnya.
Namun setelah 60 BST (Tabel 2), perlakuan penanaman dalam memiliki pertumbuhan yang lebih tinggi dan perlakuan kontrol lebih rendah dibandingkan dengan perlakuan lainnya. Analisis statistik menunjukkan bahwa sampai umur 60 BST (Tabel 2), pertumbuhan lilit batang tidak berbeda nyata antar perlakuan. Apabila dibandingkan dengan pertumbuhan tanaman karet klon IRR 118 dengan pemeliharaan yang standar pada tanah mineral (Ultisol) di kebun percobaan Balai Penelitian Sembawa tidak jauh berbeda dengan pertumbuhan tanaman karet di gambut. Hal ini menunjukkan pertumbuhan tanaman karet di lahan gambut dengan kondisi drainase yang baik tidak mengalami hambatan. 

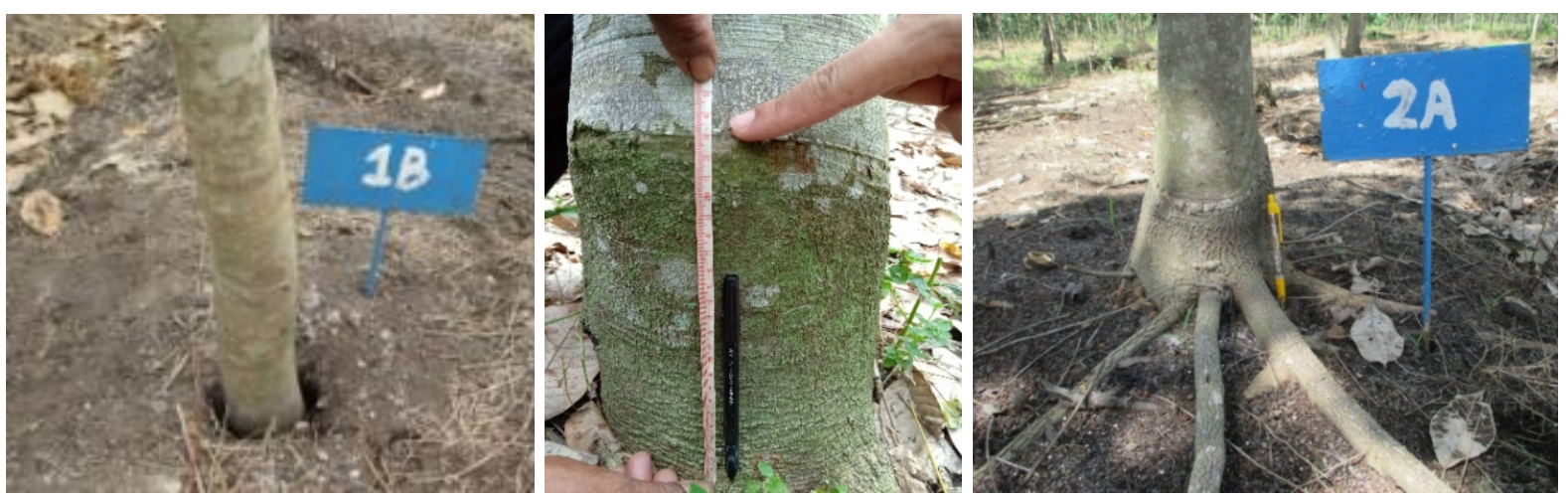

Gambar 6. Rongga di pangkal batang pada perlakuan penanaman dalam (A); Batang bawah yang sudah muncul dipermukaan pada perlakuan modifikasi bahan tanam (B); dan akar yang muncul di permukaan $(\mathrm{C})$

Figure 6. Cavities at the base of rubber plant stem for deep planting treatment (A); The rootstock that has appeared on the surface in the modification treatment of planting material (B); and roots that appear on the surface (C)

Pada penelitian ini, tanaman karet belum ada yang miring atau tumbang sampai dengan umur lima tahun. Saputra et al (2012) melaporkan bahwa tanaman karet rakyat pada lahan gambut umur lima tahun terdapat tanaman yang miring. Pada perlakuan B (penanaman dalam) terdapat rongga di dasar batang pada umur $24 \mathrm{BST}$ (Gambar 6A). Hal ini terjadi karena akar tidak tumbuh pada batang atas hasil okulasi sehingga mengakibatkan rongga di dasar batang saat adanya angin. Sementara itu, batang bawah di perlakuan C (okulasi $30 \mathrm{~cm}$ ) dan D (okulasi $50 \mathrm{~cm}$ ) seperti pada Gambar 6B sudah terlihat di atas permukaan lahan sedangkan pada perlakuan A (kontrol) sudah terlihat akarnya (Gambar 6C). Hal ini dikarenakan akumulasi subsidance (Gambar 5) yang terjadi sampai umur lima tahun sudah mencapai $\pm 25 \mathrm{~cm}$. Munculnya batang bawah dan akar di permukaan lahan akibat penurunan gambut dapat berpotensi adanya tumbang atau miring pada tanaman karet pada saat periode tanaman menghasilkan. Oleh karena itu, penelitian ini masih terus berlanjut dengan tujuan selain mengetahui efektivitas berbagai perlakuan teknik penanaman karet dalam menopang batang, namun juga dapat memberikan informasi produksi tanaman karet di lahan gambut.

\section{KESIMPULAN}

Pertumbuhan tanaman karet klon IRR 118 di lahan gambut dengan ketebalan $1,5 \mathrm{~m}$, tingkat kematangan saprik dan dengan drainase yang baik dapat mencapai matang sadap pada umur tanaman lima tahun. Pengaruh perlakuan teknik penanaman terhadap pertumbuhan dan tanaman yang miring atau tumbang sampai dengan umur tanaman lima tahun belum terlihat. Penurunan gambut selama lima tahun mencapai $25 \mathrm{~cm}$ dan penurunan tertinggi terjadi pada umur tanaman 6-18 BST. Belum terlihat adanya tanaman tumbang. Hasil pembongkaran akar tanaman menunjukkan bahwa kedalaman akar tunggang mencapai $70 \mathrm{~cm}$, hal ini menunjukkan bahwa perakaran tanaman karet tidak terendam dan berkembang dengan baik sehingga tidak mengganggu pertumbuhannya.

\section{UCAPAN TERIMAKASIH}

Penulis mengucapkan terima kasih kepada Bapak Bambang Setio atas kesediaan lahannya digunakan untuk lahan penelitian dan telah merawat tanaman dan membantu pengamatan selama penelitian 
dilakukan. Kepada Bapak Sarino, Zartomi, Syaiful dan Sahid Ali Akbar juga disampaikan ucapan terima kasih atas bantuannya selama penelitian ini berlangsung.

\section{DAFTAR PUSTAKA}

Adiwiganda, Y. T., Hardjono, A., Manurung, A., Sihotang, U. T. B. D., Sudiharto, Goenadi, D. H., \& Sihombing, H. (1994). Teknik penyusunan rekomendasi pemupukan tanaman karet. In Forum Komunikasi Karet (pp. 1-17). Sembawa, Indonesia : Pusat Penelitian Karet.

Dijkman, M. J. (1951). Hevea Thirty Years of Research in the Far East. Coral Gables, Florida, USA : University of Miami Press.

Fahmuddin, A., \& Subiksa, I. G. (2008). Lahan Gambut; Potensi untuk Pertanian dan Aspek Lingkungan. Bogor, Indonesia : Balai Penelitian Tanah dan World Agroforestry Centre (ICRAF).

Holden, J., Evans, M. G., Burt, T. P., \& Horton, M. (2006). Impact of land drainage on peatland hydrology. Journal of Environment Quality, 35, $1764-1778$.

Landry, J., \& Rochefort, L. (2012). The drainage of peatlands : impacts and rewetting techniques. Canada: Peatland Ecology Research Group, Université Laval, Québec.

Lasminingsih, M. (2013). Kondisi tajuk tanaman karet klon IRR 118. Sembawa, Indonesia: Balai Penelitian Sembawa.

Mutalib, A. A., Lim, J. S., Wong, M. H., \& Koonvai, L. (1991). Characterization, distribution and utilization of peat in Malaysia. Proc. International Symposium on Tropical Peatland. Kuching, Serawak, Malaysia.

Pertanian. (2011). Peta lahan gambut skala 1:250.000 edisi tahun 2011. Bogor: Balai Besar Penelitian dan Pengembangan Sumberdaya Lahan Pertanian. Bogor, Indonesia : BBPP SLP
Rao, P. S., \& Vijayakumar, K. R. (1992). Climatic requirements. In Sethuraj M. R. \& N.M. Mathew (Ed.), Natural Rubber: Biology, Cultivation, and Technology. Amsterdam.

Saputra, J., Ardika, R., \& Wijaya, T. (2012). Tantangan dan potensi pengembangan karet pada lahan gambut. Prosiding Konferensi Nasional Karet (pp. 241-250). Yogyakarta : Pusat Penelitian Karet.

Setiawan, \& Andoko. (2005). Petunjuk Lengkap Budidaya Karet. Jakarta, Indonesia: Agromedia Pustaka.

Sihotang, U. T. B. (1994). Prospek Lahan Gambut untuk Mendukung Pengembangan Agribisnis Karet. Warta Perkaretan, 13(3), 18-24.

Silins, U., \& Rothwell, R. L. (1999). Spatial patterns of aerobic limit depth and oxygen diffusion rate at two peatlands drained for forestry in Alberta. Canadian Journal of Forest Research, 29(1), 53-61.

Tie, Y. L., \& Lim, J. S. (1991). Characteristics and classification of organic soils in Malaysia. In Proc. International Symposium on Tropical Peatland. Kuching, Serawak, Malaysia.

Watson, W. A. (1989). Climate and soil. In C. Webster \& W. Baulkwill (Eds.), Rubber, Tropical Agriculture Series (pp. 125-164). London, UK : Longman group.

Widjaja-Adhi, I. P. G. (1988). Physical and chemical characteristic of peat soil of Indonesia. Indon. Agric Res Dev J, 10, 59-64.

Widjaja-Adhi, I. P. G. (1997). Developing tropical peatlands for agriculture. In R. J.O. \& P. S.E. (Eds.), Proceedings of the International Symposium on Biodiversity, Environmental Importance and Sustainability of Tropical Peat and Peatlands (pp. 45-54). Palangka Raya, Central Kalimantan: Samara Publishing Ltd. Cardigan. UK. 
Wijaya, T., \& Hidayati, U. (2012). Pemupukan. In M. Lasminingsih, $\mathrm{H}$. Suryaningtyas, C. Nancy, \& A. Vachlepi (Eds.), Saptabina Usahatani Karet Rakyat (6th ed.). Palembang: Balai Penelitian Sembawa.

Yew, F. K. (1991). Soil factors affecting rubber performance. Planters's Bulletin Number, 207.
Yoon, P. K., \& Leong, S. K. (1985). The Value Deep Planting in Hevea Cultivation. In International Rubber Conference. Kuala Lumpur. 